\title{
OPTIMISATION OF MIXED DRINK MADE FROM RED CABBAGE (Brassica oleracea L.) AND ROSELLE (Hibiscus sabdariffa L.) EXTRACTS
}

\author{
NUR FARAH HANI, M. ${ }^{1,2}$, HUDA-FAUJAN, N. ${ }^{1}$, HAFIZA, Y. ${ }^{1}$, FARIDAH, H. ${ }^{2}$ \\ and ARIFIN, N. ${ }^{1 *}$ \\ ${ }^{1}$ Food Biotechnology Programme, Faculty of Science and Technology, \\ Universiti Sains Islam Malaysia, Bandar Baru Nilai, 71800 Nilai, \\ Negeri Sembilan, Malaysia \\ ${ }^{2}$ Food Science and Technology Research Centre, \\ Malaysian Agricultural Research and Development Institute, \\ Persiaran MARDI-UPM, 43400 Serdang, Selangor, Malaysia \\ *E-mail: norlela@usim.edu.my
}

Accepted 14 September 2020, Published online 25 October 2020

\begin{abstract}
Response surface methodology (RSM) was employed for optimising the formulation and processing parameters of red cabbageroselle mixed drink. In this study, four independent variables namely red cabbage-roselle extracts concentration (30 to $70 \%)$, stingless honey concentration $(1-10 \%)$, pasteurisation temperature $\left(70-90^{\circ} \mathrm{C}\right)$, and pasteurisation time $(30-300 \mathrm{~s})$ were studied in order to determine the effect of the formulation (ingredients) and processing parameters towards the colour and anthocyanins content of the mixed drinks. Thirty different experimental combinations generated by RSM design were studied on the responses i.e. colour values $\left(L^{*}, a^{*}, b^{*}\right)$ and total anthocyanin content of red cabbage-roselle mixed drink. The optimal formulation and processing condition were obtained with a $70 \%$ combination of red cabbage-roselle extracts concentration and $1 \%$ of stingless honey concentration, with pasteurisation temperature, and time of $70.01^{\circ} \mathrm{C}$ and $284.07 \mathrm{~s}$, respectively. In order to verify the models, the experimental values were compared with the predicted values to check the adequacy of the models. The experimental values were found to be in agreement with those predicted, thus, indicating the suitability of the models used by RSM to optimise the formulation and processing parameters of mixed drinks made from red cabbage and roselle extracts.
\end{abstract}

Key words: Vegetable mixed juice drink; anthocyanin juice; red cabbage; roselle calyxes

\section{INTRODUCTION}

Anthocyanins are water-soluble pigments of plants often found in different fruits and vegetables. There are many fruits and vegetables in Malaysia that are abundant in anthocyanins, such as red cabbage (Saluk et al., 2012; Wiczkowski et al., 2015), roselle (Aishah et al., 2013; Da-Costa-Rocha et al., 2014; Wu et al., 2018), purple sweet potato (Aishah et al., 2013; Jiang et al., 2019), eggplant (Sadilova et al., 2006), pomegranate (Khoo et al., 2018), strawberry (Ertan et al., 2018; Khoo et al., 2018), and mulberry (Akkarachaneeyakorn \& Tintrat, 2015). Many studies have been conducted on anthocyanins due to the beautiful colouration on food products but

\footnotetext{
* To whom correspondence should be addressed.
}

also display antioxidant properties and benefits for health. Several in vitro, in vivo, and epidemiological studies also demonstrated that anthocyanins might able to prevent cancer, cardiovascular disease, and obesity (Benn et al., 2014; Jennings et al., 2012; Signorelli et al., 2015). Despite, anthocyanins are unstable and may be degraded during processing and storage, forming colourless or brown-coloured products with further loss of most of their beneficial health properties, which are undesirable characteristics in food and beverage products. (Perez-Ramirez et al., 2015; Chung et al., 2016). Stability of anthocyanin is influenced by many factors including pigment structure and concentration, light, $\mathrm{pH}$, temperature, oxygen, sugar, and sugar metabolites, interactions with ingredients, and co-pigmentation (Bordenave et al., 2014; 
Castaneda-Ovando et al., 2009). In addition, heat treatment, such as pasteurisation, is a common and efficient way of preserving beverages, which can lead to loss of quality (Kirca \& Cemeroglu, 2003).

Red cabbage (Brassica oleracea) belongs to the cruciferous vegetable group such as broccoli, cauliflower, chinese cabbage, radish, and brussel sprouts (Saluk et al., 2012). Red cabbage draws customers not only because of its nutritious and taste value, but also because of its vivid purple, or red colour (Wiczkowski et al., 2016) with anthocyanins as its main phytochemical groups (Wiczkowski et al., 2015). Red cabbage's anthocyanin composition is very complex due to glucosylation of the anthocyanidin (cyanidin) with two different sugars and acylation with several aromatic acids. The dominant structure of anthocyanins in red cabbage was cyanidin-3diglucoside-5-glucoside (Charron et al., 2009). On the other hand, roselle (Hibiscus sabdariffa) belongs to the Malvaceae family, which is a species of Hibiscus widely cultivated in tropical and subtropical regions (Zheoat et al., 2019). Roselle calyx is rich in colours, flavour, and micronutrients such as vitamin $\mathrm{C}, \mathrm{B}_{1}$ and $\mathrm{B}_{2}$ (Yaacob et al., 2006). The calyx of roselle is bright red in colour due to the presence of anthocyanins compound namely delphinidin-3-sambubioside, cyanidin-3-sambubioside, cyanidin-3-glucoside, and delphinidin-3-glucoside which are the nonmethylated type (Castaneda-Ovando et al., 2009).

Juice drinks are among the popular beverages that appeal to consumers of various age groups, including children, adolescents, adults, and elderly (Vikas Kumar et al., 2017). In recent years, drinks are not only consumed as a thirst quencher but also to improve human health and reduce the risk of chronic diseases. Among many juice, roselle juice is popular among Malaysian. However, pure roselle juice has a sour and bitter taste (Wong et al., 2002; Mgaya-Kilima et al., 2015). Juice blending is one of the best methods for enhancing the nutritional quality of the juice. Blending the roselle extract with other anthocyanin rich plant such as red cabbage can enhance the aroma, taste, nutritional and antioxidant properties of the juice blends. In Malaysia, red cabbage is underutilized and is often consumed as coleslaw and salad. In fact, application of red cabbage in food industry can be diversified, as it provides many health benefits such as anthocyanins. The mixed drink containing both extracts of roselle and red cabbage significantly contained higher anthocyanins content compared to drink that contained only roselle juice extract or red cabbage juice extract (Nur Farah Hani et al., 2019).

Response Surface Methodology (RSM) in a powerful tool for optimisation of food processes
(Baş \& Boyac1, 2007) and widely used for many application. Previously, RSM was designed by Central Composite Design (CCD) and was used to optimise the processing parameters for the clarification of blended carrot-orange juice (Karangwa et al., 2010), to optimise the formulation of Aonla squash (Jain et al., 2016), and to optimise the formulation of functional cabbage drinks with lime juice (Mohd Nazrul Hisham et al., 2017). Therefore, the purpose of this study was to derive the optimum formulation and processing parameters for the mixed drinks made from red cabbage and roselle extracts using a Central Composite Design of RSM in order to preserve the colour and anthocyanins content in the mixed drink.

\section{MATERIALS}

Red cabbage was purchased from a local supplier at Kompleks Pasar Borong Seri Kembangan (Selangor, Malaysia) while dried roselle calyxes (variety UMKL) were purchased from MARDI Kuala Terengganu (Terengganu, Malaysia). Stingless honey was purchased from Trigona Bee (Serdang, Selangor, Malaysia). Solvents and chemicals used were analytical grade and purchased from Merck (Darmstadt, Germany). Food grade chemicals were purchased from Meilun Food Chemical Sdn. Bhd. (Klang, Selangor, Malaysia) while packaging materials were purchased from Plashouse Sdn. Bhd. (Kajang, Selangor, Malaysia).

\section{METHODS}

\section{Extraction of red cabbage and roselle juice}

Initially, $300 \mathrm{~g}$ of a red cabbage head was washed under running tap water to remove foreign matters, and debris. Then, the red cabbage head was cut into six parts and was extracted using a juice extractor (Santos, France). The red cabbage extract was filtered through a muslin cloth.

Fresh roselle calyxes were dried in a mechanical dryer at $50^{\circ} \mathrm{C}$ for $28 \mathrm{hr}$ until it reached $5 \%$ moisture content. After that, dried roselle calyxes were immediately packed and sealed in aluminium polyethene bags, and kept in a chiller $\left(5^{\circ} \mathrm{C}\right)$ until analysis. Extraction of roselle calyxes was done according to the method described by Chumsri et al. (2008). Dried roselle calyxes were soaked in water at a ratio of $1: 10$, and heated at the extraction temperature of $50^{\circ} \mathrm{C}$ for $30 \mathrm{~min}$. The roselle extract was filtered through a muslin cloth. Both red cabbage and roselle juice extracts were stored in high-density polyethylene (HDPE) bottles and kept frozen $\left(-18^{\circ} \mathrm{C}\right)$ prior to the mixed drink preparation. 


\section{Preparation of mixed drink from red cabbage and roselle juice extracts}

The preliminary sensory evaluation found that a mixed drink made with red cabbage extract and roselle extract at the proportion of $4: 1$ was found to be the most accepted by panellists (Nur Farah Hani et al., 2019). Therefore, this proportion of red cabbage to roselle juice extracts $(4: 1)$ was used to optimise the formulation of the mixed drink. The mixed drinks were prepared by mixing and pasteurising the combination of red cabbage and roselle juice extracts $\left(\mathrm{X}_{1}, 30-70 \%\right)$ with other ingredients namely stingless honey concentration (X2, 1-10\%), table sugar (5\%), Arabic gum $(0.5 \%)$, citric acid $(0.1 \%)$, water $(100-\mathrm{X} 1-\mathrm{X} 2-\%$ table sugar - \%citric acid - \%Arabic gum), and sodium benzoate $(0.03 \%)$. The range of juice extracts $\left(\mathrm{X}_{1}, 30-70 \%\right)$, stingless honey concentration (X2, $1-10 \%)$, pasteurisation temperature $\left(\mathrm{X}_{3}, 70-90^{\circ} \mathrm{C}\right)$, and pasteurisation time $\left(\mathrm{X}_{4}, 30-300 \mathrm{~s}\right)$ were chosen in this study in order to study the effect of the formulation (ingredients) and processing parameters towards the colour parameters, and anthocyanin content of the mixed drinks.

Table sugar and honey were added to provide sweet taste and flavour to the mixed drinks (Kaleem et al., 2017). Stingless honey was used to partially replace the usage of table sugar, as consumption of honey especially stingless honey is becoming a trend among consumers due to its benefits such as antimicrobial, antioxidant properties and has lower glycemic index compared to table sugar (Kavita, 2011). Arabic gum is often used in beverage systems as an emulsifier or stabiliser and stable in acidic conditions (Chung et al., 2016). Citric acid was added as acidulant and to adjust $\mathrm{pH}$ while sodium benzoate was added as food preservative. The pasteurised mixed drinks were hot-filled into polypropylene (PP) bottles and cooled rapidly to room temperature $\left(27^{\circ} \mathrm{C}\right)$ by immersing the bottles in chilled water $\left(8 \pm 2^{\circ} \mathrm{C}\right)$. Then, the bottles were wrapped with aluminium foil and kept at room temperature $\left(27^{\circ} \mathrm{C}\right)$ before analysis on the next day. Anthocyanin can be diminished by exposing to light. Therefore, wrapping the bottles with aluminium foil is applied to minimise light penetration into bottle containing juice extracts.

\section{Experimental design using response surface methodology}

In this study, a $2^{4}$ full factorial central composite design (CCD) containing 30 experimental runs was employed and experiments were performed in randomised order according to the run number as arranged by Design-Expert software version 6.0.10 (Stat-Ease Inc., Minneapolis, MN, USA). According to Patras et al. (2010) anthocyanin and colour stability were affected by the intrinsic properties of the product $(\mathrm{pH}$, chemical structure and concentration of anthocyanins, co-pigments, and sugars) and the processing parameters (magnitude and duration of heating, storage temperature, and time). Therefore, four parameters namely red cabbage-roselle extracts concentration $\left(\mathrm{X}_{1}, 30\right.$ $70 \%)$, concentration of stingless honey $\left(\mathrm{X}_{2}, 1-10 \%\right)$, pasteurisation temperature $\left(\mathrm{X}_{3}, 70-90^{\circ} \mathrm{C}\right)$, and pasteurisation time $\left(\mathrm{X}_{4}, 30-300 \mathrm{~s}\right)$ were selected as independent variables.

Combination of red cabbage-roselle extracts at $50 \%$ was found to have a significant effect on anthocyanin content and colours of the mixed drink (Nur Farah Hani et al., 2019). Hence, the range of 30 to $70 \%$ red cabbage-roselle extracts concentration parameter was chosen to investigate whether the extracts concentration obtained a significant effect on stability of anthocyanins and colour of the mixed drink. Addition of honey as a sweetener into white dragon fruit juice drink obtained that panellist preferred juice sweetened with $10 \%$ of honey concentration compared to the juice sweetened with $5 \%$ and $15 \%$ honey concentration (Aji et al., 2013). Therefore, 10\% stingless honey was chosen as the maximum range for the concentration of stingless honey parameter. In order to determine juice stability, the range of pasteurisation temperature parameter was 70 to $90^{\circ} \mathrm{C}$ (Cao et al., 2011). The pasteurisation time parameter were set at $80^{\circ} \mathrm{C}, 85^{\circ} \mathrm{C}$ and $90^{\circ} \mathrm{C}$ for 30 to $300 \mathrm{~s}$ as described by Yadav (2015).

In this optimisation, the dependent variables chosen were Total Anthocyanin Content (TAC), $L^{*}$ value (lightness), $a^{*}$ value (green to redness), and $b^{*}$ value (blue to yellowness). Each independent variable had 3 levels: $-1,0$, and +1 . This is a facecentred design whereby the star points are at the centre of each face of the factorial space $(\alpha 4=4 \pm 1)$.

The RSM design generated 30 experiments $\left(T_{n} /=/ 2^{\mathrm{f}} /+/ 2 f /+/ K /=/ 2^{4} /+/ 2 / * / 4 /+/ 6 /=/ 30\right) . T_{n}$ represents the total number of experiments, $f$ represents the number of independent variables, and $K$ represents the number of centre point runs. The centre point runs provide a mean for estimating the experimental error and a measure of lack of fit. These 30 run of experiments were conducted in triplicate and the samples were analysed according to the responses. Data from the CCD were analysed by multiple regressions to fit the following secondorder polynomial model.

$Y=b_{0}+\sum_{i=1}^{4} b_{i} X_{i}+\sum_{i=1}^{4} b_{i i} X_{i}^{2}+\sum_{i=1}^{3} . \sum_{j=i+1}^{4} b_{i j} X_{i} X_{j}$

Where; $b_{0}$ is an intercept, $b_{i}$ the linear coefficient, $b_{i i}$ the quadratic coefficient, and $b_{i j}$ the interactive terms. The coded independent variables were represented by $X_{i}$, and $X_{i} X_{j}$ respectively. The 
equation was used to describe the effect of each independent variable, the combined effect of the independent variables, and the interaction effect of independent variables on the response variable $(Y)$. Coefficient determination or $R^{2}$ value, lack of fit, and significance by ANOVA at $p>0.05$ was the parameters to determine the acceptability of the polynomial model.

\section{Determination of total anthocyanin content}

Total anthocyanin content (TAC) was determined using $\mathrm{pH}$-differential method as described by Guisti and Wrolstad (2001), using potassium chloride buffer (pH 1.0) and sodium acetate buffer (pH 4.5). Mixed drink samples were mixed with the corresponding buffer, in a dilution to achieve an adequate reading of absorbance. Absorbance was recorded using UV-Vis spectrophotometer (Perkin Elmer, United Kingdom) at $520 \mathrm{~nm}$ and $700 \mathrm{~nm}$ against water as a blank. The samples to be measured should be clear and contain no sediments. Anthocyanin pigment concentration was calculated and expressed as cyanidin-3-glucoside equivalents, as following equation.

$\begin{aligned} & \text { Anthocyanin } \\ & \operatorname{pigment}(\mathrm{mg} / \mathrm{L})\end{aligned}=\frac{A \times M W \times D F \times 10^{3}}{\varepsilon \times 1}$

Where $A=\left(A_{520}-A_{700}\right) \mathrm{pH} 1.0-\left(A_{520}-A_{700}\right) \mathrm{pH}$ 4.5; $M W$ (molecular weight $)=449.2 \mathrm{~g} / \mathrm{mol}$ for cyanidin-3-glucoside (cyd-3-glu); $D F=$ dilution factor, 1 = pathlength in $\mathrm{cm}$; $\varepsilon$ (molar absorptivity) $=26,900$ molar extinction coefficients, in $\mathrm{L} \times \mathrm{mol}^{-1}$ $\times \mathrm{cm}^{-1}$, for cyanidin-3-glucoside; and $10^{3}=$ factor conversion from $\mathrm{g}$ to $\mathrm{mg}$.

\section{Determination of colour intensity}

The colour intensity for mixed drink samples was measured using Chroma Meter Minolta CR400/410 (Minolta Co., Osaka, Japan) based on $L^{*}$ $a^{*} b^{*}$ colour system which $L^{*}$ denotes lightness from black to white on a scale of 0 to 100 while $a^{*}$ and $b^{*}$ denotes the hues representing two colour axes with $a^{*}$ denotes redness $(+)$ or greenness $(-)$ and $b^{*}$ denotes yellowness $(+)$ or blueness (-).

\section{Optimisation and verification of model}

The verification of the model of optimum formulation and processing parameters of red cabbage-roselle mixed juice drink that depended on the concentration of red cabbage and roselle extracts, stingless honey concentration, pasteurisation temperature and time, was obtained using the second-order polynomial model of RSM, where the numerical optimisation method was adopted to determine the points that maximise the responses. A number of solutions were generated, and based on their desirability and suitability, the solution to be employed for the verification was selected. In order to determine the model's validity and adequacy, the experimental and predicted values of TAC and $L^{*}$, $a^{*}$ and $b^{*}$ colour space were compared and the following equation was used in order to calculate the percentage errors between the actual and predicted values.

$\operatorname{Error}(\%)=\frac{\left(V_{\text {actual }}-V_{\text {predicted }}\right)}{V_{\text {predicted }}} \times 100$

where $V_{\text {actual }}$ and $V_{\text {predicted }}$ are actual and predicted values, respectively.

\section{Statistical analysis}

The Design-Expert software version 6.0.10 (Stat-Ease Inc., Minneapolis, MN, USA) was used to develop the experimental plan for RSM. This software was also used for the regression analysis of the data obtained, to estimate the coefficients of the regression equation and to perform the analysis of variance (ANOVA).

\section{RESULTS AND DISCUSSIONS}

\section{Model fitting}

In RSM, the relationship between the variables, i.e. concentration of red cabbage and roselle extracts $\left(\mathrm{X}_{1}\right)$, stingless honey $\left(\mathrm{X}_{2}\right)$, pasteurisation temperature $\left(\mathrm{X}_{3}\right)$, and pasteurisation time $\left(\mathrm{X}_{4}\right)$ were expressed mathematically using polynomial model. The independent and dependent variables were fitted to the second-order polynomial model equation except for $L^{*}$ value (fitted for mean model) and examined for their goodness-of-fit. The analysis of variance (ANOVA) was performed to test the adequacy of the model. In order to obtain the fitted models to predict the responses, the parameters must be significant at the probability level $(p)$ equal or less than 0.05 . In this study, the responses, namely total anthocyanin content and $a^{*}$ and $b^{*}$ values were significant at $p<0.05$. However, $L^{*}$ value obtained insignificant values $(p>0.05)$ for the model response. Thus, this response was not adequate and not used for the optimisation process.

The quadratic models in terms of coded variables are shown in Equations (4), (5) and (6), where $\left(Y_{1}\right)$ represents total anthocyanin content, $\left(Y_{2}\right)$ represents $a^{*}$ (greenness or redness), and $\left(Y_{3}\right)$ represents $b^{*}$ (blueness or yellowness) as a function of concentration of red cabbage and roselle extracts $\left(X_{1}, \%, \mathrm{w} / \mathrm{w}\right)$, concentration of stingless honey $\left(X_{2}\right.$, $\%$, w/w), pasteurisation temperature $\left(X_{3},{ }^{\circ} \mathrm{C}\right)$, and pasteurisation time $\left(X_{4}, \mathrm{~s}\right)$. 
$Y_{1}=219.47+56.63 X_{1}-2.98 X_{2}-3.74 X_{3}+$ $0.70 X_{4}-30.39 X_{1}^{2}-1.17 X_{2}^{2}+4.59 X_{3}^{2}-$ $8.58 X_{4}^{2}-0.19 X_{1} X_{2}+0.67 X_{1} X_{3}-0.77 X_{1} X_{4}$ $+6.29 X_{2} X_{3}-6.36 X_{2} X_{4}-1.64 X_{3} X_{4}$

$Y_{2}=5.95+1.53 X_{1}-0.24 X_{2}-0.33 X_{3}+$ $0.077 X_{4}+1.63 X_{1}^{2}+0.77 X_{2}^{2}-2.22 X_{3}^{2}+$ $0.58 X_{4}^{2}+0.10 X_{1} X_{2}-0.15 X_{I} X_{3}+0.074 X_{1} X_{4}$ $-0.066 X_{2} X_{3}+0.47 X_{2} X_{4}-0.19 X_{3} X_{4}$

$Y_{3}=0.20-9.44 X_{1}+0.12 X_{2}-2.22 X_{3}-$ $0.05 X_{4}-0.09 X_{1}^{2}-7.46 X_{2}^{2}-0.07 X_{3}^{2}+$

$0.17 X_{4}^{2}-0.01 X_{1} X_{2}-0.01 X_{I} X_{3}+0.02 X_{1} X_{4}$

$-0.02 X_{2} X_{3}-0.05 X_{2} X_{4}+7.50 X_{3} X_{4}$

The analysis of variance of three response variables which were TAC, $a^{*}$ (redness), and $b^{*}$ (yellowness) exhibited correlation coefficients $\left(R^{2}\right)$ of $0.9824,0.7511$, and 0.9686 , respectively. Generally, $R^{2}$ values higher than 0.75 indicate the goodness-of-fit of the model (Paucar-Menacho et al., 2017). The $R^{2}$ for TAC and $b^{*}$ value was remarkably close to 1 , which exhibited that the regression models delivered meaningful explanations of the relationship between the independent factors and the responses. The smaller the value of $R^{2}$, the less relevant are the dependent variables in explaining the variation in behaviour (Little \& Hills, 1978). All models obtained a non-significant lack of fitness $(p>0.05)$, which was desirable for the model. A significant lack-of-fit might be contributions in the regressor-response relationship that are not accounted for by the model (Saniah \& Sharifah Samsiah, 2012).

\section{Total anthocyanins content}

Table 1 found that TAC in juice was significantly influenced by red cabbage and roselle calyxes extracts concentration for both linear and quadratic terms $(p<0.0001)$. The independent variable found a positive effect on the linear term and a negative effect on the quadratic term. The interaction parameters $\left(X_{2} X_{3}, X_{2} X_{4}\right)$ for TAC were significant at the level $p<0.05$. It was also a significant interaction effect between stingless honey concentration and pasteurisation temperature $\left(X_{2} X_{3}\right)$ with a positive effect on TAC, which obtained that the stingless honey concentration was dependent on the pasteurisation temperature during production of the mixed drink. It was expected that a negative interaction effect between stingless honey concentration and time of pasteurisation $\left(X_{2} X_{4}\right)$ on TAC. The TAC decreased when the stingless honey concentration and pasteurisation time were increased (Table 1$)$. In fact, a short-term thermal treatment $\left(5 \mathrm{~s}\right.$ at $\left.85^{\circ} \mathrm{C}\right)$ on strawberry juice caused $9 \%$ loss of anthocyanins while longer thermal treatment $\left(15 \mathrm{~min}\right.$ at $\left.85^{\circ} \mathrm{C}\right)$ caused $21 \%$ loss of anthocyanins (Hartman et al., 2008) indicating that longer time of thermal pasteurisation could cause a significant anthocyanin loss, even at the same pasteurisation temperature.

\section{Redness colour value}

Table 1 obtained showed that $a^{*}$ value (redness) was linearly affected by red cabbage-roselle extract concentration $\left(X_{1}\right)(p<0.01)$. The independent variable showed a positive effect on the liner term. The model found that the redness colour of juice

Table 1. Regression coefficients $\left(R^{2}\right)$ and $p$ (Probability Values) for mixed drink

\begin{tabular}{|c|c|c|c|c|}
\hline Response & TAC & $L^{*}$ & $a^{*}$ & $b^{*}$ \\
\hline Suggested model: & Quadratic & Mean & Quadratic & Quadratic \\
\hline Constant, & 219.47 & 22.01 & 5.95 & 0.20 \\
\hline$X_{1}$ - Extracts & $56.63^{\star * *}$ & & $1.53^{\star \star}$ & -9.444 E-003 \\
\hline $\mathrm{X}_{2}$ - Honey & -2.98 & & -0.24 & $0.12^{\star \star \star}$ \\
\hline $\mathrm{X}_{3}$ - Temperature & -3.74 & & -0.33 & -2.222 E-003 \\
\hline $\mathrm{X}_{4}-$ Time & 0.70 & & 0.077 & $-0.049^{* * *}$ \\
\hline$X_{1} \wedge 2$ & $-30.39^{* * *}$ & & 1.63 & $-0.087^{\star *}$ \\
\hline $\mathrm{X}_{2}^{\wedge 2}$ & -1.17 & & 0.77 & -7.456 E-003 \\
\hline $\mathrm{X}_{3}{ }^{\wedge 2}$ & 4.59 & & $-2.22^{*}$ & $-0.072^{* *}$ \\
\hline$X_{4}{ }^{\wedge 2}$ & -8.58 & & 0.58 & $0.17^{\star \star \star}$ \\
\hline $\mathrm{X}_{1} \mathrm{X}_{2}$ & -0.19 & & 0.10 & -0.011 \\
\hline $\mathrm{X}_{1} \mathrm{X}_{3}$ & 0.67 & & -0.15 & $-0.014^{*}$ \\
\hline $\mathrm{X}_{1} \mathrm{X}_{4}$ & -0.77 & & 0.074 & 0.018 \\
\hline $\mathrm{X}_{2} \mathrm{X}_{3}$ & $6.29^{*}$ & & -0.066 & $-0.019^{\star}$ \\
\hline $\mathrm{X}_{2} \mathrm{X}_{4}$ & $-6.36^{\star}$ & & 0.47 & $-0.045^{\star \star \star}$ \\
\hline $\mathrm{X}_{3} \mathrm{X}_{4}$ & -1.64 & & -0.19 & 7.500 E-003 \\
\hline $\mathrm{R}^{2}$ & 0.9824 & 0.0000 & 0.7511 & 0.9686 \\
\hline$P$ or probability & $<0.0001^{\star \star \star}$ & 0.3959 & $0.0155^{\star}$ & $<0.0001^{\star \star \star}$ \\
\hline Lack of fit & 0.1605 & $0.0003^{* *}$ & 0.8119 & 0.1451 \\
\hline
\end{tabular}

* Significant at $p<0.05 ;{ }^{* *}$ Significant at $p<0.01 ;{ }^{* * *}$ Significant at $p<0.001$ 
increased with the increment of red cabbage- roselle extract concentration in the mixed juice drinks. The red colour of cabbage-roselle mixed juice drink was due to the presence of anthocyanins in both red cabbage and roselle extracts. However, anthocyanins are easily degraded and the stability is depended on several factors such as light, $\mathrm{pH}$, storage temperature, and thermal processing (Cavalcanti et al., 2011; Naderi et al., 2015). From the table, it was also found that the quadratic term of pasteurisation temperature $\left(X_{3}^{2}\right)(p<0.05)$ showed a negative effect on the $a^{*}$ value which the higher thermal treatment caused a significant decreased of $a^{*}$ value of the red cabbage-roselle mixed juice drink. In fact, the loss of red colour in clarified pomegranate juice was also due to pasteurisation at $65^{\circ} \mathrm{C}$ for $30 \mathrm{~s}$ was lower compared to the clarified pomegranate juice pasteurised at $90^{\circ} \mathrm{C}$ for $5 \mathrm{~s}$ (Vegara et al., 2013). The brownish-red colour production during heat treatment was lead from unstable anthocyanin pigments in the fruit juices and polymerisation of anthocyanins with other phenolic compounds (Rhim et al., 1989; Maskan, 2006; Naderi et al., 2015). Colour degradation in fruits is mainly associated with the colour pigment stability (Chaikam, 2015).

\section{Yellowness colour value}

The yellowness ( $b^{*}$ value) of red cabbageroselle mixed juice drink was linearly affected by stingless honey concentration and time of pasteurisation $(p<0.001)$. Meanwhile, red cabbageroselle mixed juice drink extracts, temperature, and time of pasteurisation were quadratically significant at $p<0.001$ or $p<0.01$. It was found that the interaction parameters $\left(X_{1} X_{3}, X_{2} X_{3}\right.$, and $\left.X_{2} X_{4}\right)$ obtained negative effects on yellowness colour of mixed juice $(p<0.05$, or $p<0.001)$. The negative interaction effect between juice extracts concentration and pasteurisation temperature $\left(X_{1} X_{3}\right)$ found that $b^{*}$ value decreased with the increment of extracts concentration, and pasteurisation time. The negative interaction effect between stingless honey concentration, and pasteurisation temperature $\left(X_{2} X_{3}\right)$ to $b^{*}$ value also obtained similar trend which the $b^{*}$ value decreased with the increment of stingless honey concentration, and pasteurisation temperature. There was also a negative interaction effect between stingless honey concentration and time of pasteurisation $\left(X_{2} X_{4}\right)$ to $b^{*}$ value which the $b^{*}$ value decreased with the increment of stingless honey concentration and pasteurisation time. This result was in agreement with Zambiazi et al. (2016) which also observed a decrease in $b^{*}$ values with the increase of honey concentration in blueberry topping formulation. In addition, Cao et al. (2011) described that anthocyanin degradation and visual colour change increased by increasing the heating temperature and time of blood-orange juice.

\section{Optimisation}

The multiple response optimisations were performed using numerical optimisation function where the desired goals for the factors and responses are set. In this optimisation, the concentration of red cabbage-roselle extracts, and stingless honey were set as 'in range'. The temperature, and time of pasteurisation were set as 'minimise' and 'in range', respectively. It is desirable to have a maximum TAC and $a^{*}$ value (redness) for the mixed drink. Therefore, the goal for responses were set as 'maximise' for TAC and $a^{*}$ value (redness), while $\mathrm{b}^{*}$ value (yellowness) was set as 'in range'. The possible optimal solutions for the formulation and processing parameters for red cabbage-roselle mixed juice drink are shown in Table 2 .

Out of 10 suggested optimum solutions, solution no. 1 (70\% red cabbage-roselle mixed extracts, $1 \%$ stingless honey, pasteurisation temperature of $70.01^{\circ} \mathrm{C}$, and pasteurisation time

Table 2. Possible optimal solutions for red cabbage-roselle mixed juice drink

\begin{tabular}{cccccccccc}
\hline No. & $\begin{array}{c}\text { RC-roselle } \\
\text { extracts } \\
(\%)\end{array}$ & $\begin{array}{c}\text { Honey } \\
(\%)\end{array}$ & $\begin{array}{c}\text { Temp. } \\
\left({ }^{\circ} \mathrm{C}\right)\end{array}$ & $\begin{array}{c}\text { Time } \\
(\mathrm{s})\end{array}$ & $\begin{array}{c}\text { TAC } \\
(\mathrm{mg} / \mathrm{L})\end{array}$ & $a^{*}$ & $b^{*}$ & Desirability \\
\hline 1 & $\underline{70.00}$ & $\underline{1.00}$ & $\underline{70.01}$ & $\underline{284.07}$ & $\underline{261.339}$ & $\underline{8.606}$ & $\underline{0.064}$ & $\underline{0.998}$ & $\underline{\text { Selected }}$ \\
2 & 70.00 & 1.97 & 70.02 & 277.73 & 259.538 & 8.283 & 0.050 & 0.982 & \\
3 & 67.45 & 2.90 & 74.36 & 213.32 & 253.002 & 8.470 & 0.050 & 0.968 \\
4 & 66.50 & 1.00 & 71.81 & 300.00 & 257.496 & 8.470 & 0.127 & 0.959 \\
5 & 70.00 & 6.98 & 70.61 & 30.00 & 243.809 & 8.470 & 0.148 & 0.946 \\
6 & 67.68 & 10.00 & 70.00 & 269.80 & 234.095 & 8.470 & 0.224 & 0.930 \\
7 & 70.00 & 4.75 & 72.42 & 164.47 & 251.955 & 8.236 & 0.050 & 0.921 \\
8 & 69.92 & 10.00 & 71.79 & 80.07 & 241.648 & 8.402 & 0.306 & 0.917 \\
9 & 70.00 & 7.35 & 70.34 & 30.02 & 241.491 & 7.646 & 0.326 & 0.894 \\
10 & 65.06 & 1.00 & 75.29 & 300.00 & 251.003 & 8.970 & 0.172 & 0.879 \\
\hline
\end{tabular}

$\mathrm{TAC}=$ total anthocyanins content. 
Table 3. The predicted and actual values and residual and percentage of error from responses under optimum conditions

\begin{tabular}{cccccc}
\hline Responses & Factor & Predicted Value & Actual Value & Residual & \% Error \\
\hline \multirow{2}{*}{ TAC } & S1 & 261.339 & 261.705 & 0.366 & 0.140 \\
& S2 & 257.496 & 259.879 & 2.383 & 0.925 \\
& S3 & 251.003 & 260.124 & 9.121 & 3.634 \\
\hline \multirow{2}{*}{ a $^{*}$} & S1 & 8.606 & 8.677 & 0.071 & 0.825 \\
& S2 & 8.470 & 8.473 & 0.003 & 0.035 \\
& S3 & 8.970 & 8.950 & -0.020 & -0.223 \\
\hline \multirow{2}{*}{ b* } & S1 & 0.064 & 0.060 & -0.004 & -6.25 \\
& S2 & 0.127 & 0.120 & -0.007 & -5.512 \\
& S3 & 0.172 & 0.183 & 0.011 & 6.395 \\
\hline
\end{tabular}

TAC $=$ total anthocyanins content.

$\mathrm{S} 1$ = red cabbage-roselle extracts: $70 \%$; stingless honey: $1 \%$; temperature: $70.01^{\circ} \mathrm{C}$; time: $284.07 \mathrm{~s}$.

$\mathrm{S} 2$ = red cabbage-roselle extracts: $66.50 \%$; stingless honey: $1 \%$; temperature: $71.81^{\circ} \mathrm{C}$; time: $300.00 \mathrm{~s}$

$\mathrm{S} 3=$ red cabbage-roselle extracts: $70 \%$; stingless honey: $1 \%$; temperature: $75.29^{\circ} \mathrm{C}$; time: $300.00 \mathrm{~s}$.

of $284.07 \mathrm{~s}$ ) had better TAC and $a^{*}$ (redness) values as compared to other solutions. Besides, the desirability for this solution was 0.998 , the highest among other solutions. Therefore, this solution was considered the most appropriate formulation and processing parameters for the production of red cabbage-roselle mixed juice drink. Therefore, optimum condition of formulations and processing parameters of red cabbage-roselle mixed juice drink with $70 \%$ red cabbage-roselle extracts, $1 \%$ stingless honey, pasteurisation temperature of $70.01^{\circ} \mathrm{C}$, and time pasteurisation of $284.07 \mathrm{~s}$ were selected.

\section{Verification}

In order to verify the adequacy of the models, a number of confirmation runs were performed based on the optimal solutions generated from the RSM software. The predicted and the actual values were compared, whereas the residual and percentage error were calculated as shown in Table 3 . The calculated results revealed that the models developed were reasonably accurate. The actual values for the confirmation run were within $95 \%$ prediction interval. Results showed that the percentage error for the responses was less than $10 \%$.

\section{CONCLUSION}

Central Composite Design and Response Surface Methodology can be applied for optimising the formulation and processing parameters of red cabbage-roselle mixed juice drink. The secondorder polynomial model was used to determine the optimised formulation and processing parameters of the mixed drink. The mixed drink with a $70 \%$ red cabbage-roselle extract concentration and $1 \%$ stingless honey along with pasteurisation tempera- ture of $70.01^{\circ} \mathrm{C}$ and $284.07 \mathrm{~s}$ of pasteurisation time were the optimum conditions for the formulation and processing parameters of red cabbage-roselle mixed juice drink.

\section{ACKNOWLEDGMENTS}

This research was funded by Malaysian Agricultural Research and Development Institute (MARDI). Authors would like to thank Mr. Mohamed Nazim Anvarali for guiding in performing anthocyanins analysis and Mr. Mohd Fakhri Hashim for his kind assistance in the lab facilities.

\section{REFERENCES}

Aji, S.P., Anandito, R-B.K. \& Nurhartadi, E. 2013. Addition of various types of honey as alternative sweetener in white dragon (Hylocereus undatus) juice drink. Biofarmasi, 11(1): 13-18.

Aishah, B., Nursabrina, M., Noriham, A., Norizzah, A.R. \& Mohamad Shahrimi, H. 2013. Anthocyanins from Hibiscus sabdariffa, Melastoma malabathricum and Ipomoea batatas and its color properties. International Food Research Journal, 20(2): 827-834.

Akkarachaneeyakorn, S. \& Tinrat, S. 2015. Effects of types and amounts of stabilizers on physical and sensory characteristics of cloudy ready-todrink mulberry fruit juice. Food Science and Nutrition, 3(3): 213-220.

Baş, D. \& Boyaci, I.H. 2007. Modeling and optimization I: usability of Response Resurface Methodology. Journal of Food Engineering, 78(3): 836-845. 
Benn, T., Kim, B., Park, Y.K., Wegner, C.J., Harness, E., Nam, T.G., Kim, D.O., Lee, J.S. \& Lee, J.Y. 2014. Polyphenol-rich blackcurrant extract prevents inflammation in diet-induced obese mice. Journal of Nutritional Biochemistry, 25(10): 1019-1025.

Bordenave, N., Hamaker, B.R. \& Ferruzzi, M.G. 2014. Nature and consequences of non-covalent interactions between flavonoids and macronutrients in foods. Food and Function, 5(1): 1834.

Cao, S-Q, Liu, L. \& Pan, S-Y. 2011. Thermal degradation kinetics of anthocyanins and visual color of blood orange juice. Agricultural Sciences in China, 10(12): 1992-1997.

Castaneda-Ovando, A., Pacheco-Hernandez, M.D., Paez-Hernandez, M.E., Rodriguez, J.A. \& Galan-Vidal, C.A. 2009. Chemical studies of anthocyanins: a review. Food Chemistry, 113(4): 859-871.

Cavalcanti, R.N., Santos, D.T. \& Meireles, M.A.A. 2011. Non-thermal stabilization mechanisms of anthocyanins in model and food systems an overview. Food Research International, 44(2): 499-509.

Chaikham, P. 2015. Comparison of high hydrostatic pressure and thermal processing on physicochemical and antioxidant properties of maoberry (Antidesma thwaitesianum Müell. Arg.) juice. International Food Research Journal, 22(5): 1993-2001.

Charron, C.S., Kurilich, A.C., Clevidence, B.A., Simon, P.W., Harrison, D.J., Britz, S.J., Baer, D.J. \& Novotny, J.A. 2009. Bioavailability of anthocyanins from purple carrot juice: effects of acylation and plant matrix. Journal of Agricultural and Food Chemistry, 57(4): 12261230.

Chumsri, P., Sirichote, A. \& Itharat, A. 2008. Studies on the optimum conditions for the extraction and concentration of roselle (Hibiscus sabdariffa Linn.) extract. Songklanakarin Journal Science and Technology, 30(Supp 1): 133-139.

Chung, C., Rojanasasithara, T., Mutilangi, W. \& McClements, D.J. 2016. Stabilization of natural colors and nutraceuticals: inhibition of anthocyanin degradation in model beverages using polyphenols. Food Chemistry, 212: 596603.

Da-Costa-Rocha, I., Bonnlaender, B., Sievers, H., Pischel, I. \& Heinrich, M. 2014. Hibiscus sabdariffa L. - a phytochemical and pharmacological review. Food Chemistry, 165: 424443.
Ertan, K., Türkyılmaz, M. \& Özkan, M. 2018. Effect of sweeteners on anthocyanin stability and colour properties of sour cherry and strawberry nectars during storage. Journal of Food Science and Technology, 55(10): 4346-4355.

Guisti, M.M. \& Wrolstad, R.E. 2001. Characterization and measurement of anthocyanins by uv-visible spectroscopy, In Current Protocols in Food Analytical Chemistry. John Wiley \& Sons, New York. pp. F1.21-F1.2.13.

Hartmann, A., Patz, C.-D., Andlauer, W., Dietrich, H. \& Ludwig, M. 2008. Influence of processing on quality parameters of strawberries. Journal of Agriculture \& Food Chemistry, 56(20): 94849489.

Jain, A., Gehlot, R., Siddiqui, S. \& Jangra, M.R. 2016. Optimization of recipe for development of aonla squash - a Response Surface Methodology approach. Journal of Applied and Natural Science, 8(3): 134-1348.

Jennings, A., Welch, A.A., Fairweather-Tait, S.J., Kay, C., Minihane, A.-M., Chowienczyk, P., Jiang, B., Cecelja, M., Spector, T., Macgregor, A. \& Cassidy, A. 2012. Higher anthocyanin intake is associated with lower arterial stiffness and central blood pressure in women. The American Journal of Clinical Nutrition, 96(4): 781-788.

Jiang, T., Mao, Y., Sui, L., Yang, N., Li, S., Zhu, Z., Wang, C., Yin, S., He, J. \& He, Y. 2019. Degradation of anthocyanins and polymeric color formation during heat treatment of purple sweet potato extract at different pH. Food Chemistry, 274: 460-470.

Kaleem, M., Qazi, I.M., Arsalan, K., Muhammad Ali, K., Ibrar, H., Muhammad, A., Abid Shah, A., Falak Naz, S. \& Ata Ur, R. 2017. Effect of different concentrations of sucrose and honey on the physiochemical and sensory properties of strawberry leather. Pakistan Journal of Scientific and Industrial Research Series B: Biological Sciences, 60(1): 1-10.

Karangwa, E., Khizar, H., Rao, L., Nshimiyimana, D.S., Foh, M.B.K., Li, L., Xia, S.Q. \& Zhang, X.M. 2010. Optimization of processing parameters for clarification of blended carrot orange juice and improvement of its carotene content. Advance Journal of Food Science and Technology, 2(5): 268-278.

Kavita, M.B. 2011. Honey - an ancient functional food. Light on Ayurveda Journal, 9(4): 16-20.

Khoo, H.E., Azlan, A., Tang, S.T. \& Lim, S.M. 2017. Anthocyanidins and anthocyanins: colored pigments as food, pharmaceutical ingredients, and the potential health benefits. Food \& Nutrition Research, 61(1): 1361779. 
Kirca, A. \& Cemeroglu, B. 2003. Degradation kinetics of anthocyanins in blood orange juice and concentrate. Food Chemistry, 81(4): 583587.

Little, T.M. \& Hills, F.J. 1978. Agricultural Experimentation Design and Analysis. John Wiley, New York. pp. 170.

Maskan, M. 2006. Production of pomegranate (Punica Granatum L.) juice concentrate by various heating methods: colour degradation and kinetics. Journal of Food Engineering, 72(3): 218-224.

Mgaya-Kilima, B., Remberg, S.F., Chove, B.E. \& Wicklund, T. 2015. Physiochemical and antioxidant properties of roselle-mango juice blends: effects of packaging material, storage temperature and time. Food Science and Nutrition, 3(4): 100-109.

Mohd Nazrul Hisham, D., Saniah, K., Mohd Lip, J., Rosalizan, M.S. \& Razali, M. 2017. Optimisation of functional cabbage drinks with lime juice using Response Surface Methodology (RSM). Journal of Tropical Agriculture and Food Science, 45(2): 225-235.

Naderi, B., Maghsoudlou, Y., Aminifar, M., Ghorbani, M. \& Rashidi, L. 2015. Investigation on the changes in color parameters and turbidity of cornelian cherry (Cornus mass L.) produced by microwave and conventional heating. Nutrition and Food Sciences Research, 2(4): 39-46.

Nur Farah Hani, M., Zaiton, H., Faridah, H. \& Norlelawati, A. 2019. Physico-chemical properties and sensory acceptance of mixed drinks of red cabbage (Brassica Oleracea) and roselle (Hibiscus sabdariffa) extracts. International Food Research Journal, 26(2): 671677.

Paucar-Menacho, L.M., Martínez-Villaluenga, C., Dueñas, M., Frias, J. \& Peñas, E. 2017. Optimization of germination time and temperature to maximize the content of bioactive compounds and the antioxidant activity of purple corn (Zea mays L.) by Response Surface Methodology. LWT-Food Science and Technology, 76B: 236244.

Patras, A., Brunton, N.P., O’Donnell, C. \& Tiwari, B.K. 2010. Effect of thermal processing on anthocyanin stability in foods: mechanisms and kinetics of degradation. Trends in Food Science and Technology, 21(1): 3-11.
Perez-Ramirez, I.F., Castano-Tostado, E., Ramirezde Leon, J.A., Rocha-Guzman, N.E. \& ReynosoCamacho, R. 2015. Effect of stevia and citric acid on the stability of phenolic compounds and in vitro antioxidant and antidiabetic capacity of a roselle (Hibiscus Sabdariffa L.) beverage. Food Chemistry, 172: 885-892.

Rhim, J.W., Nunes, R.V., Jones, V.A. \& Swartzel, K.R. 1989. Kinetics of color change of grape juice generated using linearly increasing temperature. Journal of Food Science, 54(3): 776-777.

Sadilova, E., Stintzing, F.C. \& Carle, R. 2006. Anthocyanins, colour and antioxidant properties of eggplant (Solanum melongena L.) and violet pepper (Capsicum annuum L.) peel extracts. Zeitschrift für Naturforschung C, 61(7-8): 527-535.

Saluk, J., Bijak, M., Kołodziejczyk-Czepas, J., Posmyk, M.M.M., Janas, K.M. \& Wachowicz, B. 2012. Anthocyanins from red cabbage extract - evidence of protective effects on blood platelets. Central European Journal of Biology, 7(4): 655-663.

Saniah, K. \& Sharifah Samsiah, M.S. 2012. The application of stevia as sugar substitute in carbonated drinks using Response Surface Methodology. Journal of Tropical Agriculture and Food Science, 40(1): 23-34.

Signorelli, P., Fabiani, C., Brizzolari, A., Paroni, R., Casas, J., Fabriàs, G., Rossi, D., Ghidoni, R. \& Caretti, A. 2015. Natural grape extracts regulate colon cancer cells malignancy. Nutrition and Cancer, 67(3): 494-503.

Vegara, S., Martí, N., Mena, P., Saura, D. \& Valero, M. 2013. Effect of pasteurization process and storage on color and shelf-life of pomegranate juices. LWT - Food Science and Technology, 54(2): 592-596.

Vikas Kumar, H., Kaur, J., Gat, Y., Chandel, A., Suri, S. \& Panghal, A. 2017. Optimization of the different variables for the development of a cucumber-based blended herbal beverage. Beverages, 3(4): 50.

Wiczkowski, W., Szawara-Nowak, D. \& Romaszko, J. 2016. The impact of red cabbage fermentation on bioavailability of anthocyanins and antioxidant capacity of human plasma. Food Chemistry, 190: 730-740.

Wiczkowski, W., Szawara-Nowak, D. \& Topolska, J. 2015. Changes in the content and composition of anthocyanins in red cabbage and its antioxidant capacity during fermentation, storage and stewing. Food Chemistry, 167: 115-123. 
Wong, P.K., Yusof, S., Ghazali, H.M. \& Che Man, Y. 2002. Optimization of hot water extraction of roselle juice using Response Surface Methodology: a comparative study with other extraction methods. Journal of the Science of Food and Agriculture, 83(12): 1273-1278.

Wu, H-Y., Yang, K-M. \& Chiang, P-Y. 2018. Roselle anthocyanins: antioxidant properties and stability to heat and pH. Molecules, 23(6): 1-13.

Yaacob, M., Ahmad, E.I.E. \& Hussain, Y. 2006. Manual Penanaman Roselle. Serdang: MARDI.
Yadav, T.V. 2015. Effect of heat processing on $\beta$ carotene and ascorbic acid content of carrot-fruit juice blended nectar. The Bioscan, 10(2): 699703.

Zambiazi, R.C., Jansen, C., Bueno-Costa, F.M., Silva, S.S.D. \& Hartwig, N. 2016. Bioactive compounds and antioxidant activity of blueberry toppings with honey. International Food Research Journal, 23(6): 2375-2383.

Zheoat, A.M., Gray, A.I., Igoli, J.O., Ferro, V.A. \& Drummond, R.M. 2019. Hibiscus acid from Hibiscus sabdariffa (Malvaceae) has a vasorelaxant effect on the rat aorta. Fitoterapia, 134: 5-13. 